\title{
Role of CYP1B1 in PAH-DNA adduct formation and breast cancer risk
}

\author{
Goth-Goldstein $\mathrm{R}^{1}$, Russell $\mathrm{ML}^{1}$, Li $\mathrm{D}^{2}$, Müller $A P^{3}$, Caleffi $\mathrm{M}^{3}$, \\ Eschiletti $J^{4}$, Graudenz $\mathrm{M}^{3}$, Sohn $\mathrm{MD}^{1}$ \\ ${ }^{1}$ Lawrence Berkeley National Laboratory \\ Environmental Energy Technologies Division \\ Berkeley, California 94720 \\ ${ }^{2}$ M.D. Anderson Cancer Center \\ University of Texas \\ Houston, Texas 77054 \\ ${ }^{3}$ Hospital Moinhos de Vento \\ Porto Alegre, Brazil \\ ${ }^{4}$ Clinica Rio Branco \\ Porto Alegre, Brazil
}

April 2010

This work was supported by USAMRMC Grant No. DAMD 17-1-01-0290 and the Director, Office of Science, of the U.S. Department of Energy under Contract No. DE-AC02$05 \mathrm{CH} 11231$.

Correspondence may be addressed to R. Goth-Goldstein, Lawrence Berkeley National Laboratory, One Cyclotron Road, Mailstop 70R0108B, Berkeley, CA 94720 or by email to R_Goth-

Goldstein@lbl.gov 


\section{Abstract}

This study investigated the hypothesis that increased exposure to polycyclic aromatic hydrocarbons (PAHs) increases breast cancer risk. PAHs are products of incomplete burning of organic matter and are present in cigarette smoke, ambient air, drinking water, and diet. PAHs require metabolic transformation to bind to DNA, causing DNA adducts, which can lead to mutations and are thought to be an important pre-cancer marker. In breast tissue, PAHs appear to be metabolized to their cancer-causing form primarily by the cytochrome P450 enzyme CYP1B1. Because the genotoxic impact of PAH depends on their metabolism, we hypothesized that high CYP1B1 enzyme levels result in increased formation of PAH-DNA adducts in breast tissue, leading to increased development of breast cancer. We have investigated molecular mechanisms of the relationship between PAH exposure, CYP1B1 expression and breast cancer risk in a clinic-based case-control study. We collected histologically normal breast tissue from 56 women (43 cases and 13 controls) undergoing breast surgery and analyzed these specimens for CYP1B1 genotype, PAH-DNA adducts and CYP1B1 gene expression. We did not detect any difference in aromatic DNA adduct levels of cases and controls, only between smokers and nonsmokers. CYP1B1 transcript levels were slightly lower in controls than cases, but the difference was not statistically significant. We found no correlation between the levels of CYP1B1 expression and DNA adducts. If CYP1B1 has any role in breast cancer etiology it might be through its metabolism of estrogen rather than its metabolism of PAHs. However, due to the lack of statistical power these results should be interpreted with caution. 


\section{Introduction}

Breast cancer is the most commonly occurring cancer among women and the second leading cause of cancer mortality in the United States (Boring et al., 1992). The etiology of breast cancer remains largely unknown. The role of family histories, reproduction and hormonal factors has been well documented, but accounts for less than half the cases (Madigan et al., 1996). Environmental factors such as urban residency, lifestyle and high fat diet also seem to contribute to breast cancer, but a direct relationship with specific exposures has not been clearly established. In this study, we have investigated the potential role of a group of environmental and dietary contaminants, polycyclic aromatic hydrocarbons (PAHs), in the pathogenesis of breast cancer. PAHs are formed during incomplete combustion of fossil fuels and from other industrial sources. They are ubiquitous in the environment and found in air and the human diet. The following observations support a role of PAHs: 1. In rodents many PAHs give rise to breast tumors. 2. Breast tissue is a significant storage depot for PAHs. 3. Normal human mammary cells metabolize PAHs efficiently. 4. PAH-DNA adducts have been detected in breast tissue and their levels were higher in the breast tissue of breast cancer patients than of noncancer controls (Li et al., 1996). 5. The mutational spectrum in the p53 gene in breast tumors differs significantly from that attributed to endogenous or background mutations, but resembles that in lung cancers where the role of environmental agents such as PAHs is well established (Biggs et al., 1993).

The genotoxic impact of PAHs depends on their metabolism to more reactive intermediates. The major pathway by which ingested or inhaled PAHs are metabolized, is the stepwise oxidative activation by the cytochrome P450 isozymes, CYP1A1 and CYP1B1, followed by detoxification by phase II enzymes (Nebert and Gonzales, 1987). The highly reactive intermediate formed by CYP1A1 or CYP1B1 can bind to DNA, and the resulting DNA adduct can cause a mutation that, if occurring in a relevant gene, could initiate cancer. Therefore DNA adducts are considered biomarkers of potential cancer risk. Expression of the $C Y P 1 A 1$ and $C Y P 1 B 1$ genes is inducible by PAHs and other environmental toxins, such as dioxin (Safe, 1995), so gene expression analysis captures the convergence of multiple genetic and environmental factors that influence metabolic enzyme levels (Gonzalez and Gelboin, 1994; Whitlock, 1999).

Whereas CYP1A1 has been studied extensively for decades, much less is known about CYP1B1, one of the newest members of the P450 family of enzymes. CYP1B1 could be a key enzyme in the activation of carcinogens in the breast and therefore play a role in the development of breast cancer: 1 . The $C Y P 1 B 1$ gene is highly expressed in human breast tissue (Larsen et al., 1998; Goth-Goldstein et al., 2003). 2. Besides activating lipophilic environmental carcinogens, such as PAHs and aromatic amines, the CYP1B1 enzyme also seems to have an endocrine regulatory role in hydroxylating $17 \beta$-estradiol at the $\mathrm{C}-4$ position to the potentially carcinogenic 4 -hydroxy estradiol (Shimida et al., 1996; Hayes et al., 1996). 3. When investigating PAH-induced lymphomas in mice, the frequency of lymphomas was reduced to one tenth in CYP1B1 null mice compared to wild-type mice, indicating that CYP1B1 is critical for carcinogenesis by certain PAHs and that extrahepatic metabolism is important in determining susceptibility to PAHs (Buters et al., 1999). 
PAH-DNA adducts provide the most direct link between exposure to PAHs and cancer. Because the genotoxic impact of PAH depends on their metabolism, high CYP1B1 enzyme levels may result in increased formation of PAH-DNA adducts in breast tissue, subsequently leading to development of breast cancer (Lagueux et al., 1999). In this study we set out to investigate the underlying molecular mechanisms of the relationship between PAH exposure and breast cancer risk and to test the following hypothesis:

1. Increased PAH-DNA adduct formation is associated with increased risk of invasive breast cancer.

2. Increased $C Y P 1 B 1$ gene expression is associated with increased risk of invasive breast cancer.

3. Increased $C Y P 1 B 1$ gene expression is associated with increased PAH-DNA adduct formation in breast cells.

The hypotheses that were tested are illustrated in Figure 1.

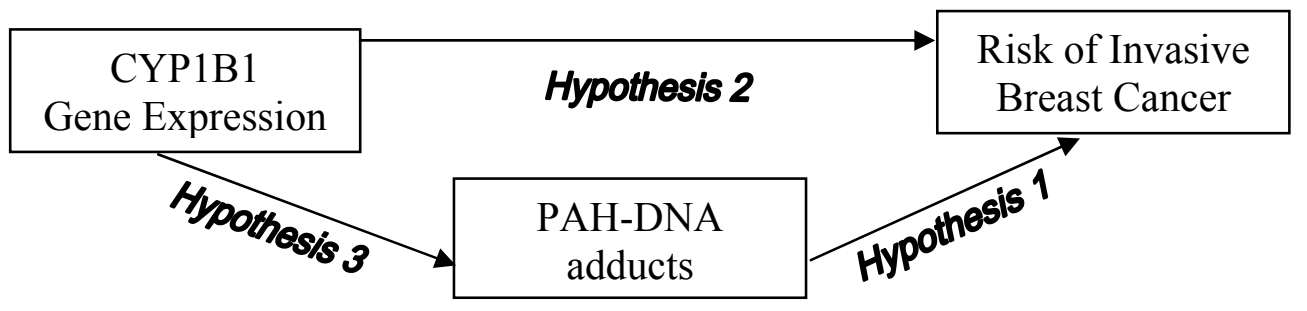

Figure 1. Relationship of the Four Hypotheses

Because the association between PAH exposure and disease risk would be easier to detect in a highly exposed population, we chose as study site Porto Alegre in the South of Brazil where we suspected that frequent barbecued meat consumption, smoking and limited air pollution controls would result in higher PAH exposure for women than in the United States. Using a clinic-based case-control design, breast tissue was obtained from female patients undergoing either mastectomy or reduction mammoplasty surgery in Porto Alegre, Brazil. PAH exposure and potential confounding-factor data were collected for all cases and controls via medical chart review and an interviewer-administered questionnaire. To characterize molecular level interindividual variation in PAH metabolism, $C Y P 1 B 1$ gene expression and PAH-DNA adducts were measured in the surgically-obtained histologically normal breast tissue from women undergoing mastectomy or reduction mammoplasty surgery.

\section{Material and Methods}

Recruitment of Study Participants: To test our hypothesis we collected normal breast tissue from cases undergoing mastectomy and controls undergoing reduction mammoplasty surgery at two recruitment hospitals in Porto Alegre, Brazil with the help of two collaborating surgeons, 
one specializing in breast diseases, the other in breast reconstruction and reduction mammoplasty. Candidate patients were identified (inclusion criteria for all: no prior diagnosis of cancer and usual residence in the state of Rio Grande do Sul, Brazil; additionally for cases: no chemotherapy or radiation therapy prior to mastectomy; and additionally for controls: no history of atypical hyperplasia, atypia, or other benign proliferative disease). Candidate patients were invited to participate in the study and informed consent to participate in the study was obtained before surgery. Enrollment of participants was much slower than anticipated. We only recruited 54 cases and 15 controls for descriptive data collection, and because the recorded date of consent was ambiguous for four of these participants, we proceeded with 52 cases and 13 controls for tissue analysis.

Data Collection: Through a questionnaire administered by trained interviewers and through medical record abstraction we collected information regarding known or suspected breast cancer risk factors and medical histories, as well as information on possible sources of PAH exposure, such as smoking, exposure to second hand smoke, combustion sources from heating and cooking and consumption of grilled, fried and smoked food. Breast tissue was obtained during scheduled surgeries, processed and stored in a stabilizing buffer (RNALater, Ambion) at $-20^{\circ} \mathrm{C}$ until shipment to the USA.

\section{DNA and RNA Isolation from breast epithelial cells}

DNA was isolated by the Proteinase K - phenol/chloroform methods from the 57 specimens received. We had originally proposed to isolate the DNA together with RNA in the TRI Reagent procedure, but found that this method yielded only small amounts of low-quality DNA. DNA was quantitated and its purity determined by its $260 / 280 \mathrm{~nm}$ absorption. Samples were stored at $-80^{\circ} \mathrm{C}$ in small aliquots for later measurements of both CYP1B1 genotype and DNA adducts.

Total RNA was isolated using TRI Reagent following the manufacturer's protocol (Molecular Research Center, Inc., Cincinnati, OH). The isolated RNA was resuspended in ribonuclease-free $5 \mathrm{mM}$ TE, $\mathrm{pH} 7.5$ and then reverse transcribed immediately, as described below. RNA was isolated from HMEC 184 cells for use as a positive control. The quality and quantity of RNA was determined spectrophotometrically, then the RNA samples were stored at $-80^{\circ} \mathrm{C}$.

CYP1B1 genotype analysis: The CYP1B1 genotype at codon $432(\mathrm{~m} 1)$ and at codon $453(\mathrm{~m} 2)$ was analyzed by PCR /RFLP. Using the primers described by Bailey et al. (1998, corrections, 1999) a 144 bp product is amplified. This product can be used to detect both the $\mathrm{m} 1$ and $\mathrm{m} 2$ polymorphisms. The $\mathrm{m} 1$ (Val to Leu) polymorphism is detected by digestion with the restriction enzyme Eco571, which produces $83 \mathrm{bp}$ and $61 \mathrm{bp}$ fragments in the variant. The $\mathrm{m} 2$ (Asp to Ser) polymorphism is detected by digestion with Cac8I, which produces 106bp and 38bp fragments in the variant. The digestion products are separated on a $10 \%$ native polyacrylamide gel stained with SYBR Gold (Figure 2).

Measurement of aromatic DNA adducts in breast tissue: Aliquots of DNA isolated from breast epithelial tissue were shipped to Dr. Donghui Li, a Co-Investigator at the M.D. Anderson Cancer Center, for DNA adduct analysis. Aromatic DNA adduct levels were determined by the nuclease P1-enhanced version of the ${ }^{32} \mathrm{P}$-post-lableing assay as described in Li et al. (1996), which involves stepwise DNA digestion to nucleosides, conversion to ${ }^{32} \mathrm{P}$-labeled 
deoxyribonucleosides, purification and separation by multidirectional TLC. Adducts were detected and quantitated by image analysis. Adduct levels are expressed as a relative adduct level (RAL) value, which is a ratio of the counts per minute (cpm) of modified nucleotides over the cpm of total nucleotides in the reaction. The detection limit of adducts is 1 per $10^{9}$.

Quantitation Standard (QS): The CYP1B1 RNA QS containing the 164 bp CYP1B1 target sequence was obtained by cloning a $311 \mathrm{bp}$ fragment of cDNA (expressed from a HMEC 184 cell line) spanning exon 2 and exon 3 of the CYP1B1 genome into a bacterial cell line. Briefly, the $311 \mathrm{bp} \mathrm{CYP1B1}$ fragment was ligated into a pGEM vector (obtained from Promega) creating a pCYP1B1 vector. Competent E. coli cells (JM109) were transformed with the pCYP1B1 vector. Using the proper selection media, the transformed bacteria were grown, then colonies were selected and screened for the presence of the pCYP1B1 vector. Large quantities of the pCYP1B1 vector were isolated and purified. After linearizing the pCYP1B1 vector, the RNA CYP1B1 QS standard was produced by in vitro translation. A fluorescent assay was used to accurately determine the concentration of the purified CYP1B1 QS.

External Quantitation of CYP1B1 with a Real-time RT-PCR Assay: An equal amount (500 ng) of total RNA isolated from each specimen was added to each RT-PCR reaction. A five-point dilution series of the CYP1B1 RNA QS standard, ranging from $1 \mathrm{fg}$ to $10,000 \mathrm{fg}$, was included with each set of specimen measured with this assay. Each reaction included a negative control, a positive control (RNA isolated from HMEC 184 cell line) and a reverse transcription control. Before reverse transcription, RNA secondary structure was removed by heating RNA with $0.25 \mu \mathrm{g}$ random primers for 4 minutes at $72^{\circ} \mathrm{C}$, then immediately chilling the sample in an ice bath. The RNA/primer mixture was reverse transcribed using 200 units of Moloney-murine leukemia virus reverse transcriptase (M-MLV RT) and 40 units of a ribonuclease inhibitor in a reaction buffer comprised of $50 \mathrm{mM}$ Tris, $\mathrm{pH} 8.3,75 \mathrm{mM} \mathrm{KCl}, 3 \mathrm{mM} \mathrm{MgCl}, 20 \mathrm{mM}$ dithiothreitol and $0.5 \mathrm{mM}$ dNTPs in a $20 \mu \mathrm{L}$ reaction volume for $25^{\circ} \mathrm{C}$ for $10 \mathrm{~min}$. followed by 1 hour at $42^{\circ} \mathrm{C}$. The resulting cDNA was stored at $-80^{\circ} \mathrm{C}$ or amplified immediately.

The quantitation of the 164 base pair (bp) CYP1B1 PCR product generated by primers CYP1B101 and CYP1B1-06 (see Table 1) was performed using a rapid air microcapillary cycler with real-time product detection by fluorescence (LightCycler, Roche Molecular Biochemicals). Five microliters of cDNA was amplified using the LightCycler-FastStart DNA Master Mix reagent (Roche Molecular Biochemicals) with a final concentration of 40 pmol each primer and $6 \mathrm{mM}$ $\mathrm{MgCl}_{2}$. A serial dilution of an external quantitation standard (CYP1B1 QS) was included with each group of samples that are amplified. PCR amplification was followed by melting curve analysis to assure the presence of a single PCR product.

Table 1. CYP1B1 RT-PCR Primer sequences.

\begin{tabular}{|l|l|l|}
\hline Primer & Sequence & Position (bp) \\
\hline CYP1B1-01 & 5'-CGTACCGGCCACTATCACTG & $1303-1322$ \\
\hline CYP1B1-06 & 5'-CCATACAAGGCAGACGGTCCCT & $1442-1463$ \\
& & \\
\hline
\end{tabular}




\section{Results and Discussion}

\section{Characteristics of Study Participants}

Women were between 27 and 71 years of age (Table 2) with the control population being somewhat younger $($ mean $=47)$ than the case population $($ mean $=54)$. From the questionnaires we learned that all participants were white and were mostly well educated with about half of the participants holding a university degree, and many working as teachers. Alcohol consumption in participants was low: 4 women reporting drinking 0-1 drink per day and only three women reported drinking 2 or more drinks per day. All others did not consume any alcohol.

Table 2. Characteristics of study population

\begin{tabular}{|c|c|c|}
\hline & $\begin{array}{l}\text { Cases } \\
(n=54)\end{array}$ & $\begin{array}{l}\text { Controls } \\
(n=15)\end{array}$ \\
\hline $\begin{array}{l}\text { Age at time of surgery, mean } \pm \text { SD } \\
\text { (range) }\end{array}$ & $\begin{array}{l}54.08+9.0 \\
(37-71)\end{array}$ & $\begin{array}{l}47.27 \pm 11.29 \\
(27-70)\end{array}$ \\
\hline Past menopause (\%) & $36(67)$ & $8(53)$ \\
\hline $\begin{array}{l}\text { Education - highest degree } \\
\text { High school completed }(\%) \\
\text { University degree }(\%)\end{array}$ & $\begin{array}{ll}12 & (22) \\
30(56)\end{array}$ & $\begin{array}{l}8(53) \\
5(33)\end{array}$ \\
\hline $\begin{array}{l}\text { Family history of breast cancer } \\
\text { In } 1^{\text {st }} \text { degree relative }(\%) \\
\text { In } 2^{\text {nd }} \text { degree relative }(\%)\end{array}$ & $\begin{aligned} & 8(15) \\
& 11(20) \\
&\end{aligned}$ & $\begin{array}{ll}1 & (7) \\
3 & (20) \\
\end{array}$ \\
\hline Previous benign breast disease & $5(9)$ & 0 \\
\hline Age at menarche & 12.4 & 12.3 \\
\hline Age at $1^{\text {st }}$ child & $25.7 \pm 5.3$ & $24.7 \pm 3.9$ \\
\hline \# of birth & 2.4 & 2 \\
\hline Total months of breastfeeding (range) & $9.4(0-44)$ & $8.5(0-30)$ \\
\hline Nulliparous (\%) & $9(17)$ & $1(7.7)$ \\
\hline Use of HRT $(\%)$ & $21(58)$ & $5(63)$ \\
\hline Exercise (in hours per week) & 2.4 & 3.9 \\
\hline
\end{tabular}


Information about possible exposure of participants to PAHs in indoor air, in diet and by use of coal tar-containing shampoo is summarized in Table 3. Potential PAH exposure sources in indoor air and through smoking were similar for cases and controls, whereas the diet of controls consisted of much less PAH-containing food.

Table 3: Potential Exposure to PAHs

\begin{tabular}{|l|c|c|}
\hline & $\begin{array}{l}\text { Cases } \\
(n=54)\end{array}$ & $\begin{array}{l}\text { Controls } \\
(n=15)\end{array}$ \\
\hline $\begin{array}{l}\text { Heating/Cooking with wood or } \\
\text { open fire (\%) }\end{array}$ & $11(20)$ & $3(20)$ \\
\hline Smoking Status & $9(17)$ & $4(27)$ \\
Former smoker (\%) & $10(19)$ & $1(7)$ \\
Current smoker (\%) & $21(39)$ & $5(33)$ \\
\hline $\begin{array}{l}\text { Exposure to } \\
\text { Second Hand Smoke (\%) }\end{array}$ & $3.0(0-17)$ \\
\hline $\begin{array}{l}\text { Diet - mean portions per week of } \\
\text { Grilled meat (range) }\end{array}$ & $3.8(0-13)$ & $0.4(0-4)$ \\
$\quad$ Smoked meat & $1.7(0-14)$ & $0.7(0-3)$ \\
$\quad$ Toasted cheese and bread & $3.6(0-26)$ & 1 \\
\hline Total portions & 9.1 & 1 \\
\hline $\begin{array}{l}\text { Use of coal tar containing shampo } \\
\text { times or more per week }\end{array}$ & 2 & \\
for last 10 years & & \\
\hline
\end{tabular}

For cases, $68 \%$ were diagnosed with invasive ductal carcinoma, 17\% with ductal carcinoma in situ (DCIS) and $15 \%$ with other tumors; $19 \%$ of cases had axilary node involvement; $83 \%$ of tumors were estrogen receptor, positive, $85 \%$ progesterone receptor positive, $26 \%$ p53 positive and $13 \%$ had Her2 overexpression.

\section{CYP1B1 Polymorphism}

Beside the overall level of exposure the genetic background of the exposed individual may alter the health consequences of exposure. Genetic variation in the CYP1B1 gene may play a role in interindividual differences in the metabolism of PAHs and estrogen. Therefore the CYP1B1 genotype at two polymorphic sites located in the catalytic side of the enzyme at codon $432(\mathrm{~m} 1)$ and at codon $453(\mathrm{~m} 2)$ was analyzed by PCR / RFLP.

Fig. 2 gives an example of the gels used to determine the genotype.

The results from the genotype analysis are summarized in Table 4. We calculated the allele frequencies for the two polymorphic sites and compared them to reports of allele frequencies observed in different ethnic groups (Table5). The allele frequencies determined in our small sample set resemble those seen in populations of European descent. 


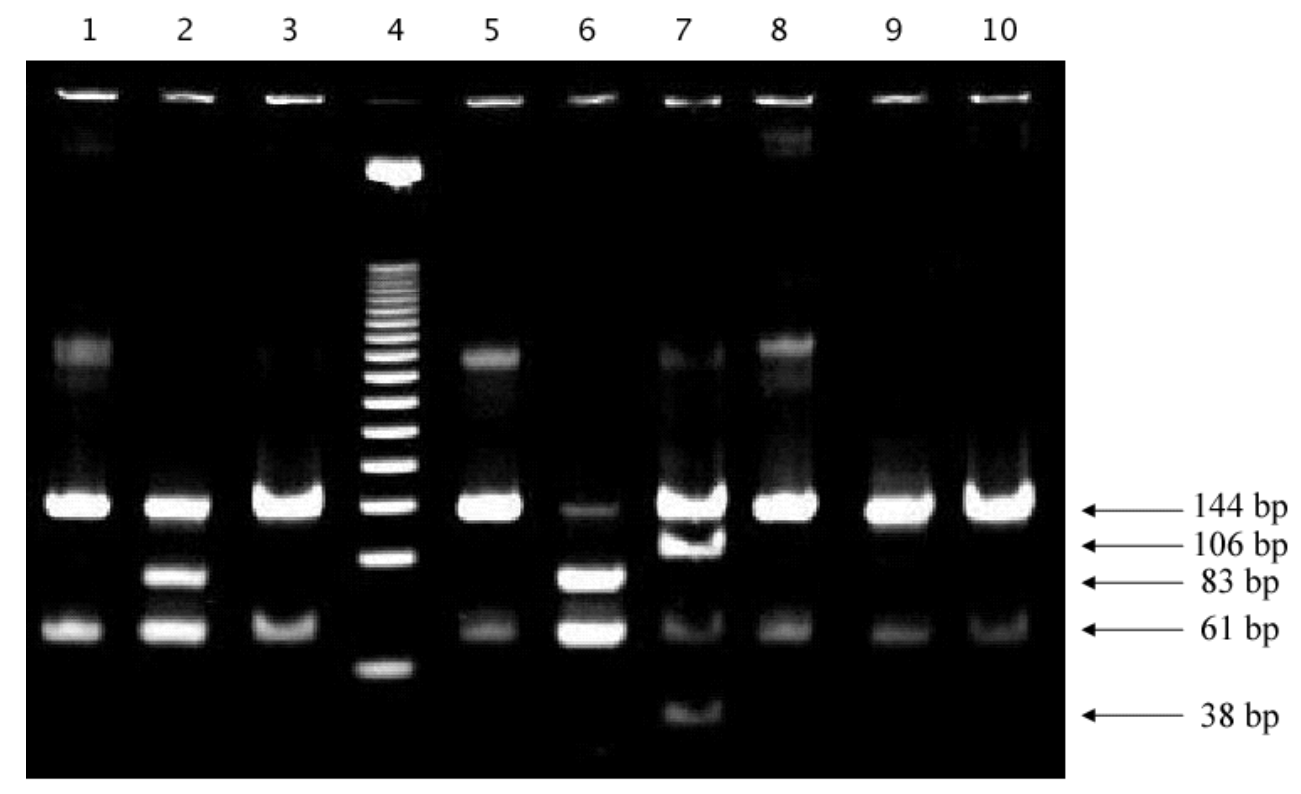

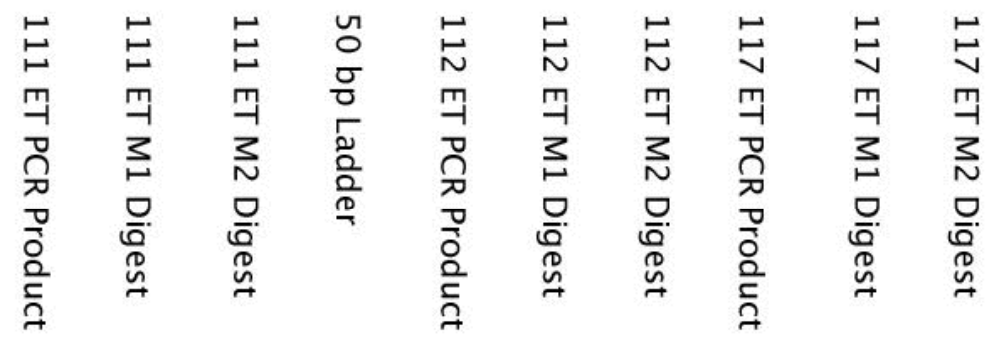

Figure 2: This gel shows the results for 3 specimens. Lane 1, 5, 8 contain the undigested PCR product (144 bp); lane 2, 6 and 9 contain the $\mathrm{m} 1$ digestion products (144bp, $83 \mathrm{bp}$ and $61 \mathrm{bp}$ ); lane $3,7,10$ contain the $\mathrm{m} 2$ digestion products (144bp, $106 \mathrm{bp}$ and $38 \mathrm{bp}$ ). Extraneous bands are visible at approximately $65 \mathrm{bp}$ and $400 \mathrm{bp}$.

Table 4. $C Y P 1 B 1$ genotype of 64 participants

\begin{tabular}{|cc|c|c|c|}
\hline \multicolumn{2}{|c|}{ CYP1B1 genotype } & Total & Controls & Cases \\
\hline $\mathrm{m} 1$ & Val/Val & 9 & 2 & 7 \\
\hline & Val/Leu & 35 & 10 & 25 \\
\hline & Leu/Leu & 20 & 1 & 19 \\
\hline $\mathrm{m} 2 \quad$ Asn/Asn & 46 & 11 & 35 \\
\hline & Asn/Ser & 17 & 2 & 15 \\
\hline \multicolumn{2}{|c|}{ Ser/Ser } & 1 & 0 & 1 \\
\hline
\end{tabular}


Table 5. Comparison of $C Y P 1 B 1$ allele frequency in participants and in different ethnic groups (given as means of several published reports)

\begin{tabular}{|l|l|l|l|l|}
\hline Codon & Participants & African Descent $^{1.3}$ & Asian Descent $^{2,3}$ & Europ. Descent $^{1,2}$ \\
\hline 432 Val & 0.414 & 0.703 & 0.154 & 0.404 \\
\hline 432 Leu & 0.586 & 0.297 & 0.846 & 0.596 \\
\hline 453Asn & 0.852 & 0.975 & 0.997 & 0.807 \\
\hline 453Ser & 0.148 & 0.025 & 0.003 & 0.193 \\
\hline
\end{tabular}

${ }^{1}$ Bailey et al., 1998; ${ }^{2}$ Inoue et al., 2000; ${ }^{3}$ Mammen et al.,2003.

The small number of participants included in our study does not allow any conclusions on the relationship of these polymorphisms to breast cancer risk. A number of studies have investigated the role of the CYP1B1 Val432Leu polymorphism in breast cancer risk and results have been inconclusive. A recent meta-analysis of all published case control studies found that results depended on ethnic background and that a possible association of the Val genotype with breast cancer was suggested only for Caucasians (Paracchini et al., 2007). This genotype was also identified as a modifier of breast cancer risk in Finnish Caucasian women who smoke and/or who carry the N-acetyl transferase slow acetylator genotype (Sillanpää et al. 2007). A recent study (Justenhoven et al., 2008) identified a significantly increased breast cancer risk for carriers of the CYP1B1 453 Ser genotype $(\mathrm{OR}=2.57: 95 \% \mathrm{CI}$ : 1.34-4.93) using single factor analyses, however no significant association was observed by multifactor analyses.

\section{Aromatic DNA Adducts in Breast Tissue}

PAH DNA adducts were quantified by the ${ }^{32} \mathrm{P}$-postlabeling assay as described in the Method section. For 9 specimens, not enough DNA was obtained for adduct analysis. But even for the remaining DNA samples we encountered problems. Preserving tissue in RNALater, a supersaturated salt buffer, appears to cause problems for DNA adduct measurements. We presume that carry-over of salts from the RNALater inhibits nuclease digestion of the isolated DNA. We modified the DNA isolation protocol to use a low-salt buffer and reprecipitate the DNA to remove these salts. In 2 specimens no adducts were detected.

The ${ }^{32} \mathrm{P}$-postlabeling analysis separates a large number of bulky DNA adducts, almost all of them unidentified. Various types of DNA adduct patterns of normal breast tissues are shown in Figure 3. Figure 3 A exemplifies a commonly observed pattern, Figure 3 B shows the typical smokingrelated diagonal radioactive zone, the pattern of Figure $3 \mathrm{C}$ was detected only in a single participant. It corresponds to the benzo[a]pyrene-like DNA adduct observed by Li et al. (1996) in normal breast tissue of about $40 \%$ of cases, but not in any controls. The origin of this adduct is still unclear (Li et al., 2002).

The results of the quantitative analysis of the chromatograms are summarized in Table 6, while Figure 4 depicts the distribution of adduct levels in cases and controls. We did not observe a difference between cases and controls in adduct levels of normal breast tissue. DNA adduct levels appear to increase with age (data not shown). However, this might be due to the higher adduct levels in smokers, as there were more women with a smoking history in the higher age group. 

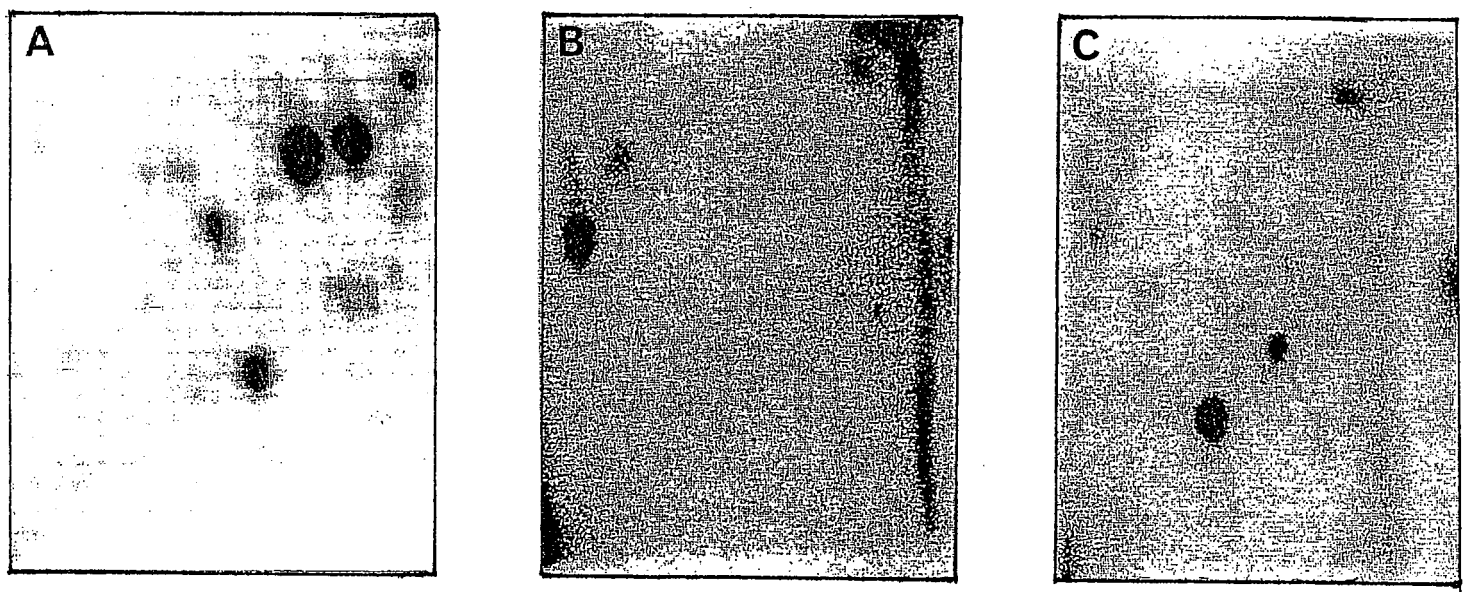

Figure 3: ${ }^{32} \mathrm{P}$-labeled DNA adduct profiles in normal breast tissue; A: typical adduct pattern; B: smoking-related adduct pattern, C: benzo[a]pyrene-like adduct described by Li et al. (1996).

Li et al. had reported in 1996 that DNA adduct levels in normal breast tissue of women with breast cancer were higher than in healthy controls recruited from around Houston. We had chosen Porto Alegre, Brazil as study site because we expected high PAH exposures due to limited air pollution controls and the local diet, which includes frequent barbecued meat consumption. However, even though DNA adduct measurements were done by the same method and in the same laboratory, the mean DNA adduct level $\left(30.3 \pm 24.8\right.$ per $10^{9}$ nucleotides, range $2.29-100.6$ per $10^{9}$ nucleotides) was less than a third of that reported by Li et al. in 1996 (97.4 per $10^{9}$ nucleotides, range $3.8-1737$ per $10^{9}$ nucleotides), and as mentioned above, we found no evidence for a difference in PAH-DNA adduct levels of cases and controls. Comparing the means using the two-tailed Students test the $p$-value $=0.95(p$-value of $\log$ (means) $\simeq 0.89, p$ value on variance $\simeq 0.29$ ). This does not indicate that cases and controls are the same, but merely reflects that with so few control samples, the statistics do not allow us to discriminate between them.

Table 6. PAH-DNA adducts determined in breast tissue (expressed as RAL x $10^{9}$ )

\begin{tabular}{|l|l|l|l|}
\hline & Mean (SD) & Median & Range \\
\hline Total $(n=53)$ & $31.5(24.3)$ & 23.25 & $2.29-100.6$ \\
\hline Controls $(n=12)$ & $32.8(29.7)$ & 20.2 & $6.76-92.9$ \\
\hline Cases $(n=41)$ & $31.1(22.8)$ & 23.3 & $2.29-100.6$ \\
\hline
\end{tabular}



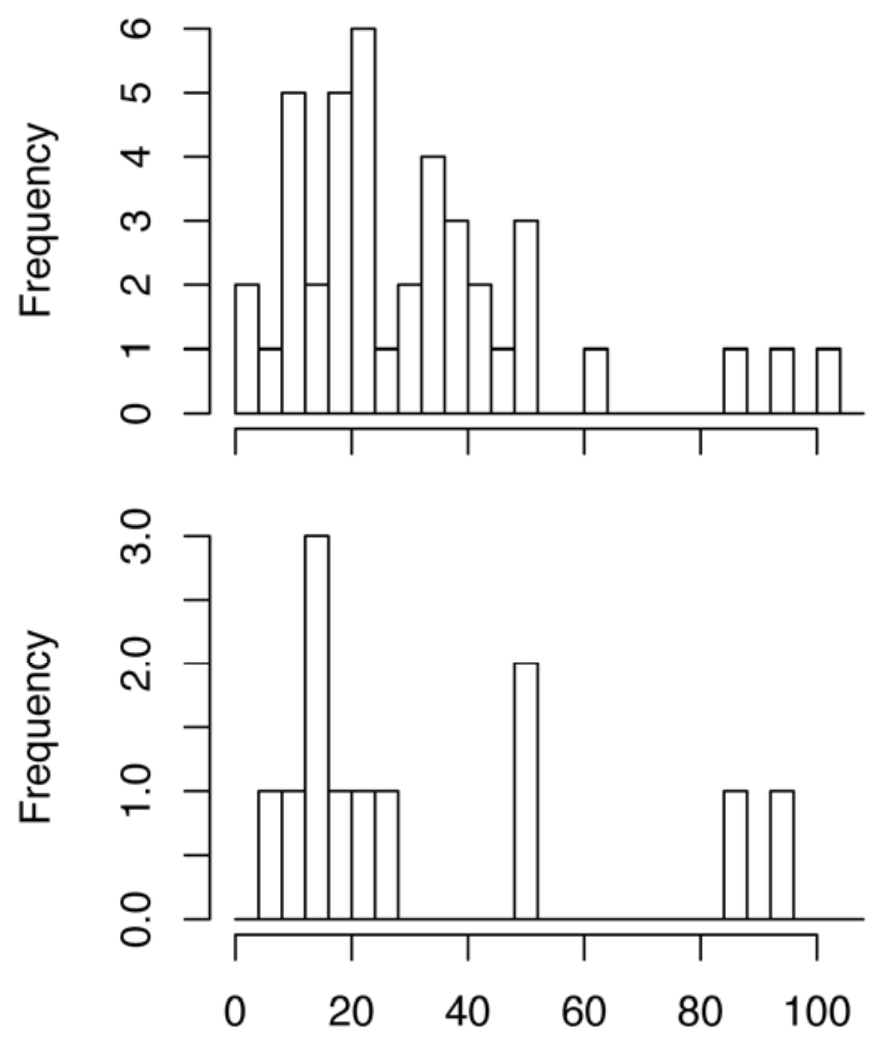

Adducts

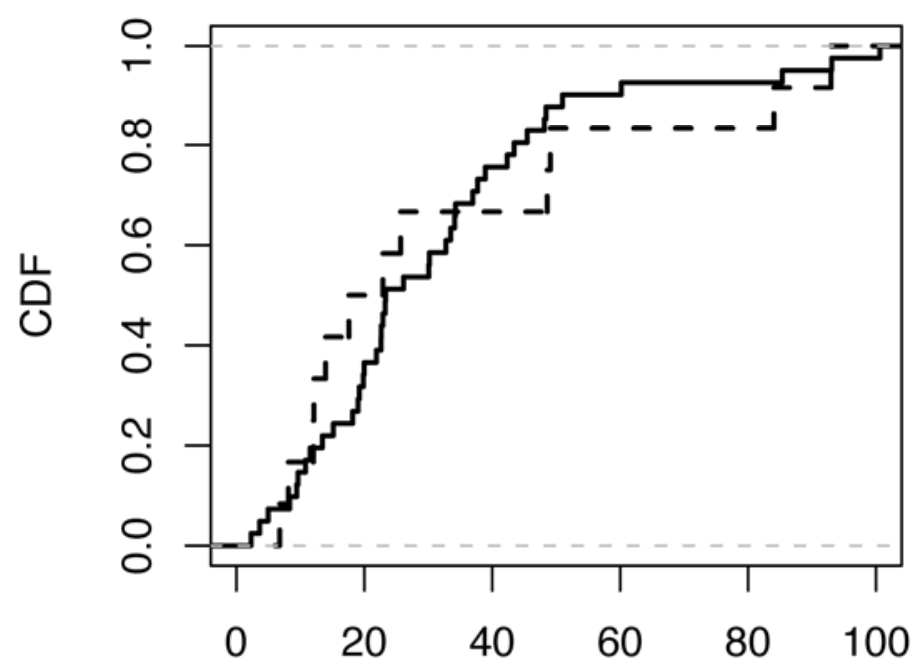

Adducts

Figure 4: Aromatic DNA adduct levels displayed as histogram (top panel - cases, middle panel - controls) and as cumulative distribution function (bottom panel; solid line - cases, dotted line - controls). 
In the Long Island breast cancer study where PAH DNA adducts in blood samples of over 2200 women were measured by ELISA, the results provided only a modest support for an association between PAH DNA adducts and breast cancer development (Gammon et al., 2002).

The benzo[a]pyrene-like DNA adduct (Figure 3 C) described by Li et al. (1996) was observed in a single participant, a nonsmoker and control. Interestingly, the woman reported using coal tarcontaining shampoo daily in the last 10 years. Weyand et al. (2000) found that coal tarcontaining shampoo applied to the shaved backs of mice produced significant levels of DNA adducts in lung tissue indicating dermal absorption of the coal tar. The various adducts included a benzo[a]pyrene-like adduct (Weyand, personal communication). This might indicate that frequent use of coal tar-containing shampoo can lead to dermal uptake of the coal tar and result in detectable DNA adducts at distant sites. We identified one other participant who reported using coal tar containing shampoo daily, but the DNA adduct panel was not as pronounced as in the first one. The amount of tissue obtained from the participant was not sufficient for further isolation and characterization of this adduct.

\section{CYP1B1 expression in breast tissue samples}

Of the 65 breast tissue specimens analyzed for CYP1B1 transcript levels, 7 did not give any results or only non-specific PCR product. The values for the 58 specimens that gave results are summarized in Table 7 and the distribution of expression levels is shown in Figure 5. As we have observed previously (Goth-Goldstein et al., 2003), expression levels in these breast tissue specimens vary over a broad range with a more than 1000 fold variation. The mean and median transcript level of controls was lower than that of cases, but the difference was not statistically significant $(p$-value $=0.1823)$. This could be due to lack of statistical power.

Table 7. $C Y P 1 B 1$ expression in 58 breast tissue specimens analyzed. Transcript levels are expressed as fg/500ng total RNA used in the reverse transcription.

\begin{tabular}{|c|c|c|c|}
\hline & $\begin{array}{c}\text { CYP1B1 } \\
\text { Mean (SD) }\end{array}$ & $\begin{array}{c}\text { CYP1B1 } \\
\text { Median }\end{array}$ & range \\
\hline Total $(\mathrm{n}=58)$ & $20.9(19.9)$ & 18.35 & $0.06-73.7$ \\
\hline Control $(\mathrm{n}=12)$ & $14.0(15.7)$ & 7.56 & $0.08-38.2$ \\
\hline Cases $(\mathrm{n}=46)$ & $22.7(20.6)$ & 21.0 & $0.06-73.7$ \\
Inv. Duct. Carc. $(26)$ & $18.4(17.3)$ & 16.42 & $0.06-68.95$ \\
DCIS $(\mathrm{n}=8)$ & $42.2(21.0)$ & 42.8 & $0.54-73.7$ \\
\hline
\end{tabular}



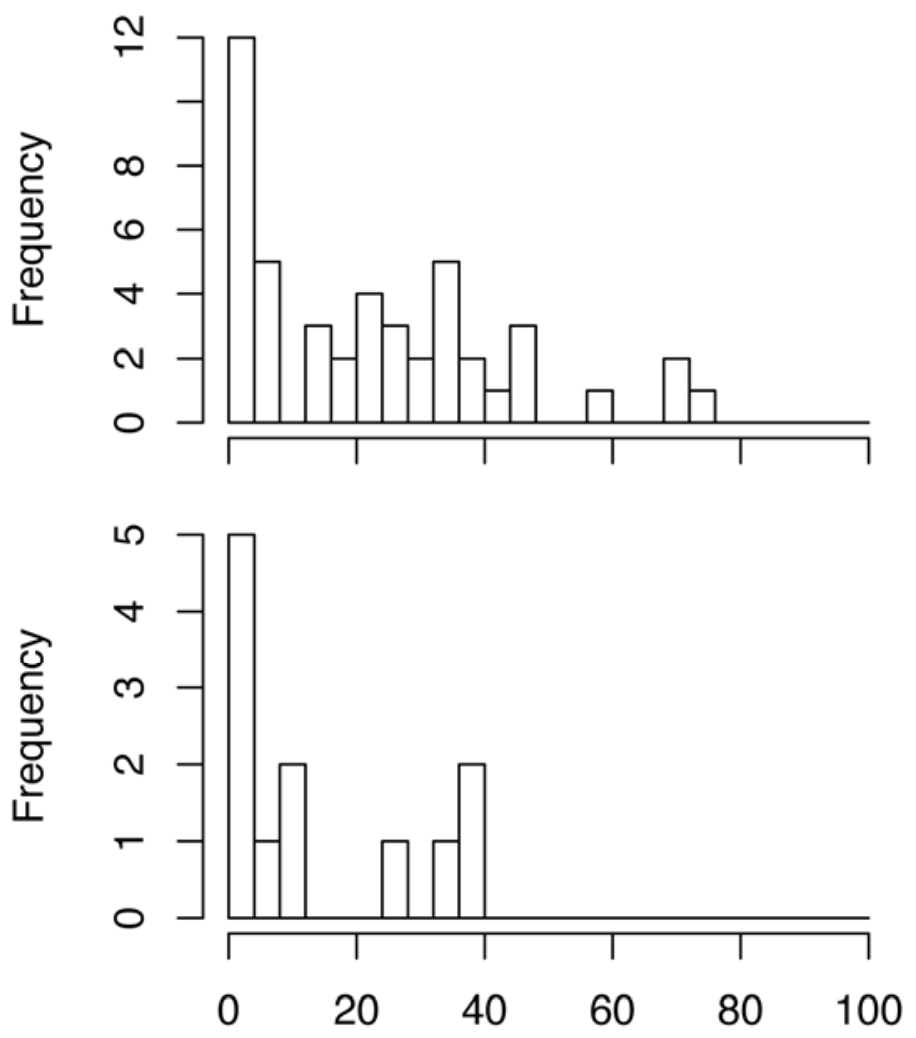

Expression

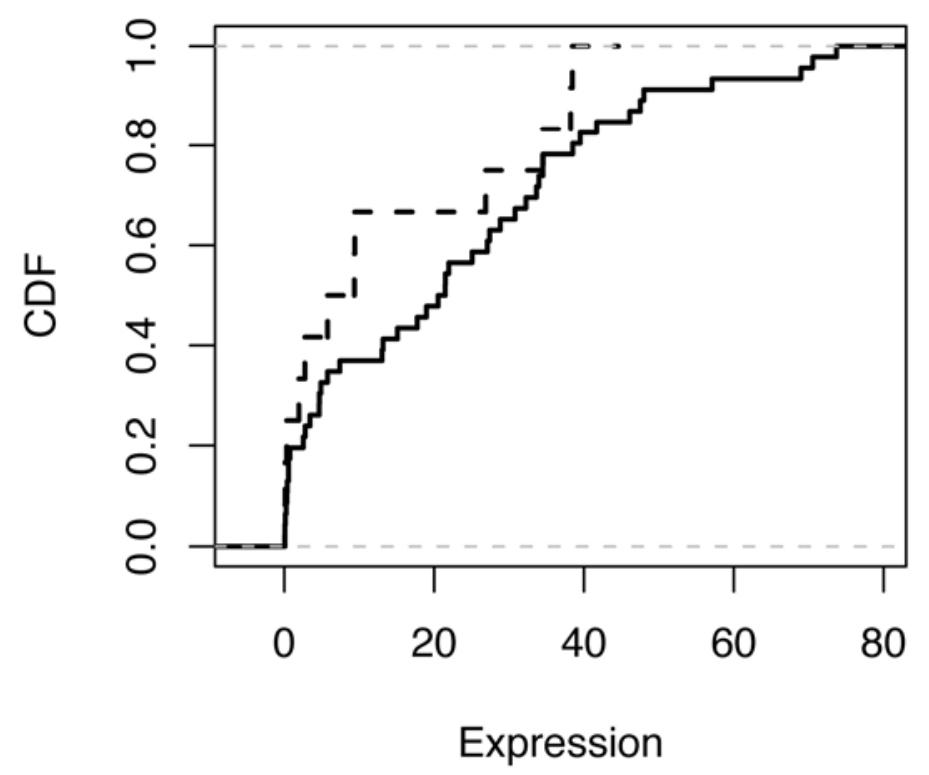

Figure 5: CYP1B1 transcript levels (in fg/500ng total RNA) displayed as histogram (top panel cases, middle panel - controls) and as cumulative distribution function (bottom panel; solid line cases, dotted line - controls). 
In evaluating our hypothesis that increased $C Y P 1 B 1$ gene expression is associated with increased risk of invasive breast cancer, we found that the mean and median CYP1B1 transcript levels in breast tissue of controls were lower than those of cases, but this difference was not statistically significant ( $p$-value $=0.1823$ ). Again, this might be due to low sample number and lack of statistical power. In an earlier study using a semiquantitative assay, we did observe a significant difference in CYP1B1 expression level in breast tissue of cases compared to controls (GothGoldstein et al., 2003). The data from the current and earlier study cannot be combined for analysis, as different methods were used and the populations were different. Others have also reported significantly higher $C Y P 1 B 1$ expression in breast tissue of breast cancer patients compared to benign breast disease (Wen et al., 2007). Surprisingly cases with DCIS had a higher transcript level than cases with invasive ductal carcinoma (Table 7); seven of the eight cases with DCIS had transcript levels above $30 \mathrm{fg} / 500 \mathrm{ng}$ total RNA and tumors with this histology contributed greatly to the high end values in the histogram. In contrast to our earlier findings (Goth-Goldstein et al., 2003) we did not observe lower CYP1B1 transcript levels in postmenopausal women (data not shown).

At the onset of our study we had assumed that $C Y P 1 B 1$ gene expression is predominantly regulated through the Ah receptor pathway, which is induced by exposure to environmental chemicals, including PAHs (Gonzalez and Gelboin, 1994; Whitlock, 1999). Therefore we expected that high CYP1B1 transcript levels capture environmental exposures. In interim it has become apparent that the $C Y P 1 B 1$ gene expression regulation is very complex and includes $C Y P 1 B 1$ gene silencing through hypermethylation of promoter $\mathrm{CpG}$ islands (Widschwendter et al., 2004) and translational repression through microRNA (Tsuchiya et al., 2006) and these mechanisms might play a role during malignant transformation.

If the CYP1B1 enzyme plays any role in modifying breast cancer risk it might be due to its metabolism of estrogen rather than metabolism of PAHs. Like a number of P450 enzymes CYP1B1 metabolizes $17 \beta$-estradiol, but it is the only one of these enzymes that predominantly catalyzes hydroxylation at the $\mathrm{C}-4$ position. The resulting 4-hydroxyestradiol imparts estrogenic activity and is considered potentially carcinogenic. The other P450 enzymes produce predominantly 2-hydroxyestradiol, which has antiestrogenic properties (Zhu and Conney, 1998). 


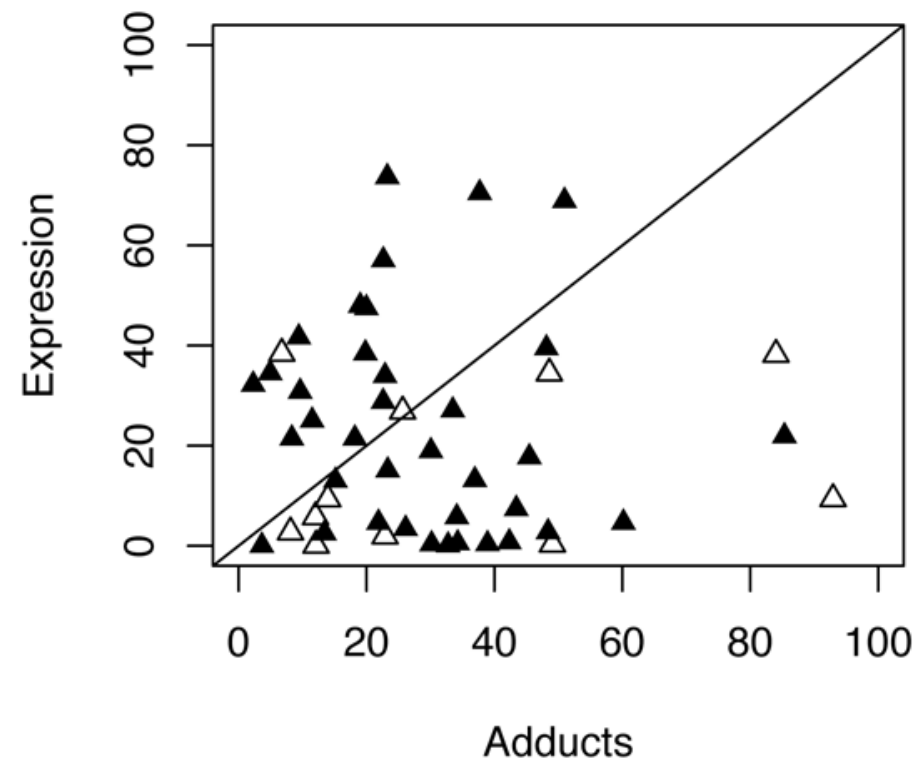

Figure 6: Level of CYP1B1 expression (fg/500ng total RNA) versus aromatic DNA adducts $\left(\mathrm{RAL} \times 10^{9}\right)$. Open triangles - controls; solid triangles - cases.

There is no indication of a linear relationship between CYP1B1 expression level and PAH-DNA adducts (Figure 6). The Spearman coefficients is $\rho=-0.05$.

\section{Effect of PAH Exposure on DNA adduct level and CYP1B1 expression}

In an exploratory analysis, we considered the influence as estimated by interviewer-administered questionnaires, of various PAH exposure sources on CYP1B1 gene expression and PAH-DNA adduct levels.

There was no association of aromatic DNA adduct levels or CYP1B1 transcript level with heating or cooking sources or with second hand smoke exposure (data not shown). When evaluating intake of grilled, smoked or toasted food individually (data not shown) or combined intake of food prepared by any of these three methods we also did not observe any clear association (Figure 7) and the observed higher intake of cases in PAH-containing food was not reflected in higher adduct levels. Even in studies with larger populations, the relationship between environmental exposures and DNA adduct levels remain unclear (Steck et al., 2007). Only for smoking did we see a difference in both DNA adduct levels and CYPIB1 expression. As can be seen in Figure 8, participants who identified themselves as current or former smokers showed increased DNA adduct levels and increased CYP1B1 transcript levels. It appears that smoking overwhelmed all other indicators of exposure to PAHs. 

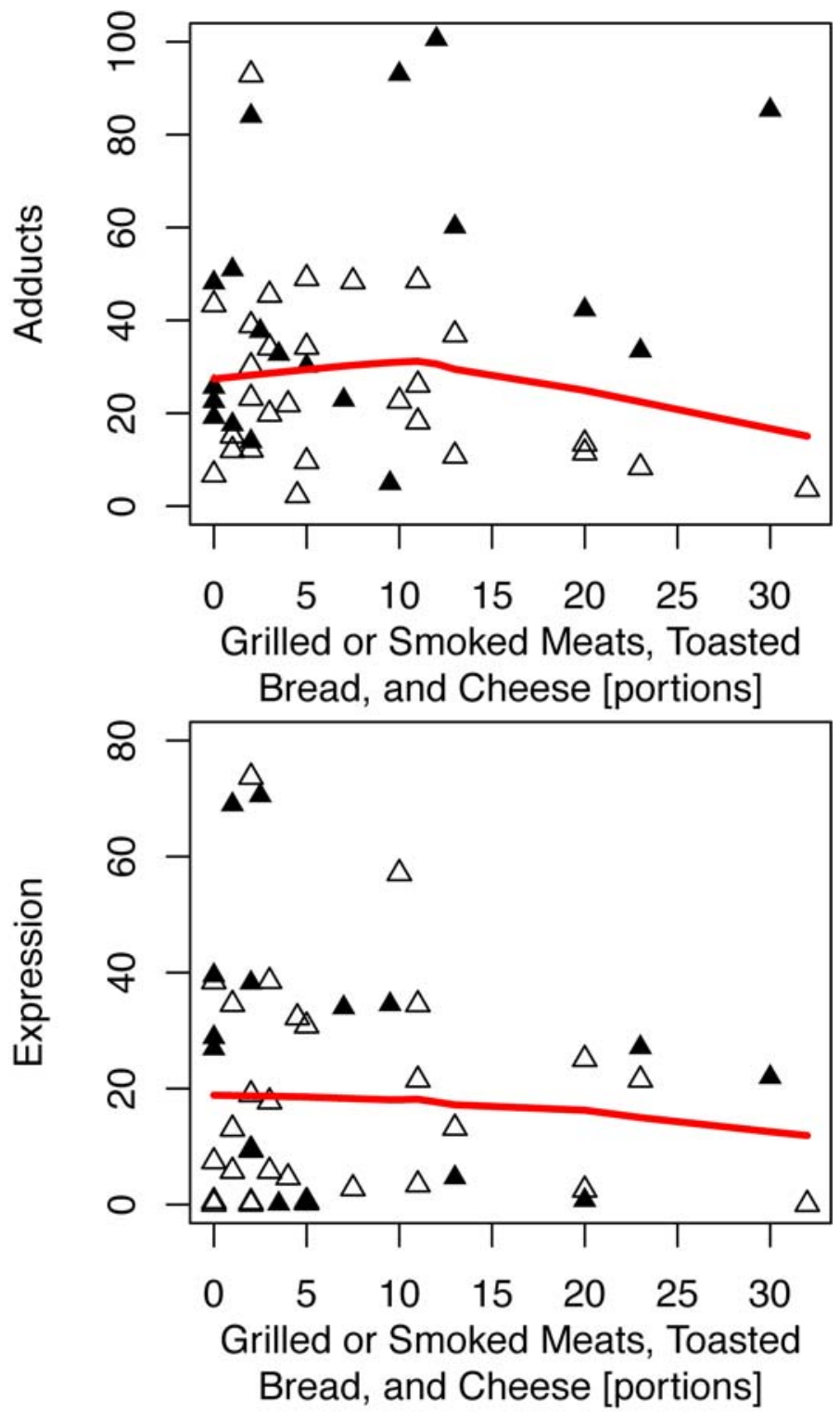

Figure 7: The effect of diet (combined portions per week of grilled or smoked meat and toasted cheese and bread) on DNA adducts levels (left panel) and CYP1B1 transcript level (right panel). Solid triangles represent current or former smokers and open triangles nonsmokers. 

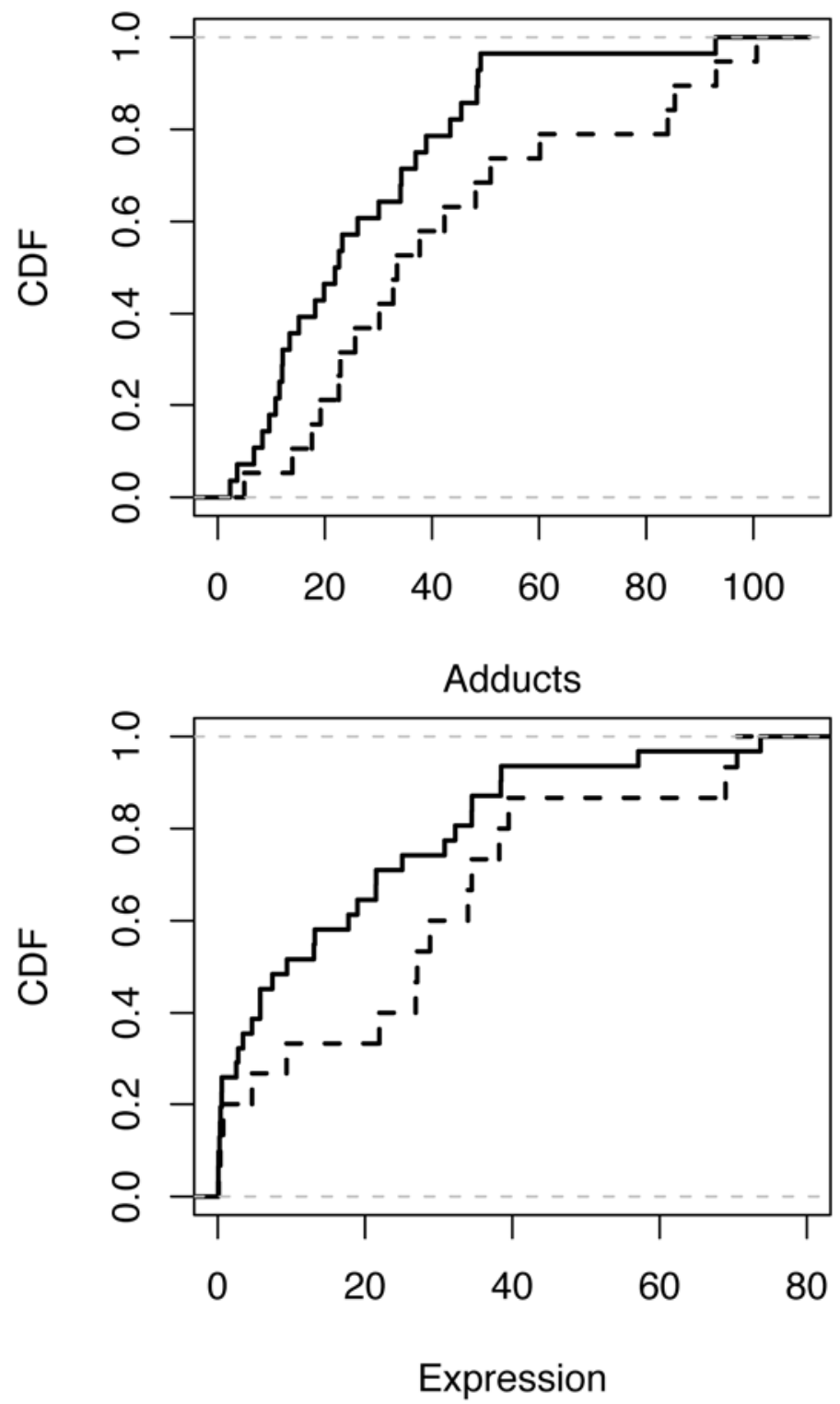

Figure 8: The effect of smoking on DNA adducts levels (left panel) and CYP1B1 transcript level (right panel) shown as cumulative distribution. Solid lines represent non smokers and dotted lines current and former smokers.

Interestingly, three former smokers who according to their questionnaire answers had started smoking at age 16 to 18 and had stopped smoking more than 15 years ago, maintained high adduct levels. This agrees with the findings by Wiencke et al. (1999) and might indicate that smoking during adolescence can produce physiologic changes that lead to decreased transcription-couple repair and increased DNA adduct persistence. Unfortunately, with the limited study size, we are unable to explore this hypothesis in greater detail. 
Shantakumar et al.(2005) reported inconsistent associations between detectable PAH-DNA adducts, such as grilled and smoked foods or a summary measure of total dietary BaP intake during the year prior to an interview. They concluded that the PAH-DNA adducts detected in a population-based sample of adult women with ambient exposure levels reflect some key residential PAH exposure source, such as cigarette smoking. The authors suggested that season may be a better surrogate of dietary PAH intake and recent ambient PAH exposure than the other measures used in their study. Because of this observation, we evaluated the association of DNA adduct levels and the season during tissue collection (Table 8). Surprisingly, we observed the highest adduct level in winter and spring, even when all current and former smokers were eliminated. However, as noted above, we did not find an association between DNA adduct levels and open heating or cooking sources or second hand smoke exposure. Unfortunately, due to our small sample size, and the large variability in the results, more advanced statistical analyses were not warranted at this time; we did not want to read into the data beyond what our best judgment suggested. Future work to pool these results with others reported in the literature could be fruitful, but is beyond the scope of this paper.

Table 8. Seasonable variation in mean DNA adducts

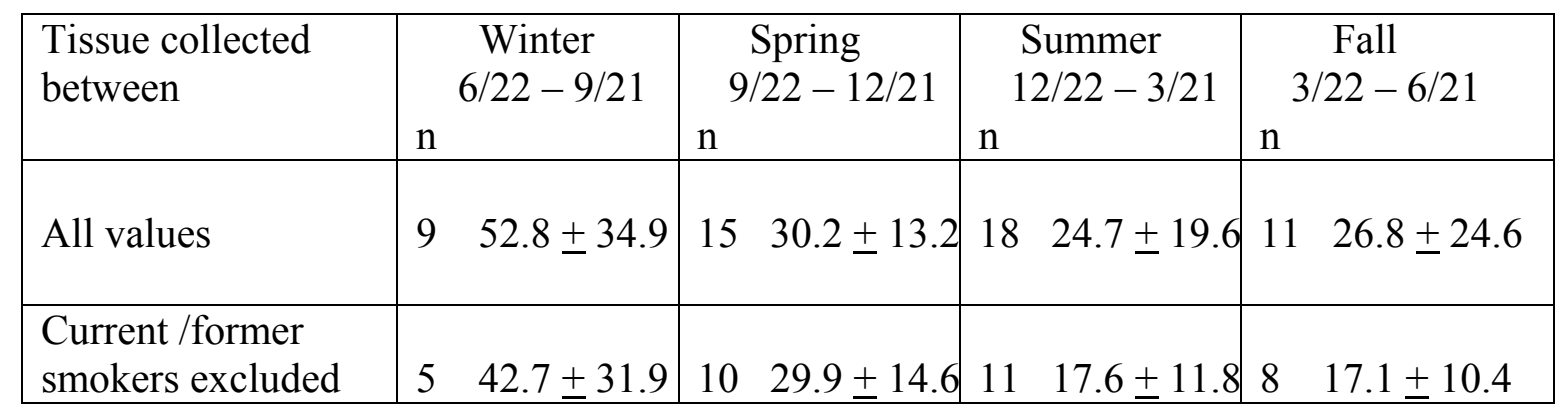

\section{CONCLUSIONS}

Because the genotoxic impact of PAH depends on their metabolism, we hypothesized that high CYP1B1 enzyme levels result in increased formation of PAH-DNA adducts in breast tissue, leading to increased development of breast cancer. We tested the hypothesis that individuals with higher CYP1B1 expression are at a higher risk for breast cancer because they produce higher amounts of ultimate carcinogen. In a previous study we had found that CYP1B1 expression was higher in normal breast tissue samples from cancer patients than from healthy controls (Goth-Goldstein et al., 2003). In the current study we found a difference in CYPIBI expression in cases and controls, but the difference was not statistically significant. We did not detect any difference in aromatic DNA adduct levels and no correlation between levels of $C Y P 1 B 1$ expression and DNA adduct (increased CYP1B1 gene expression was not associated with increased PAH-DNA adduct formation in breast cells). This might be because there is no association or because the small sample size did not allow us to detect the relationship. Future studies with larger sample sizes are therefore essential to overcome the inherent interindividual variability of gene expression and large variation in environmental exposure history. Given the 
small dataset, we should consider joining our data with other datasets, then study various associations and confounders.

\section{ACKNOWLEDGEMENT}

This work was supported by USAMRMC Grant No. DAMD 17-1-01-0290 and the Director, Office of Science, of the U.S. Department of Energy under Contract No. DEAC02-05CH11231. The study was approved by the UC Berkeley Committee for Protection of Human Subjects (2003-8-148) and the Brazilian National Ethics Committee (CONEP 9114). We thank C.A. Erdmann for her major role in the design of the study, John Deacon for performing most of the polymorphism analysis and Tom McKone for valuable suggestions.

\section{REFERENCES}

Bailey, L.R., Roodi, N., Dupont, W.D., Parl, F.F. (1998) Association of cytochrome P4501B1 (CYP1B1) polymorphism with steroid receptor status in breast cancer. Cancer Res. 58: 5038-5041. Erratum in Cancer Res 59:1388, 1999.

Biggs P, Warren W, Venitt S, Stratton M. (1993) Does a genotoxic carcinogen contribute to human breast cancer? The value of mutational spectra in unraveling the aetiology of cancer. Mutagenesis 8: 275-283.

Boring CC, Squires TS, Tong T (1992) Cancer statistics, 1992. CA Cancer J Clin 42:19-38.

Buters JT, Sakai S, Richter T, Pineau T, Alexander DL, Savas U, Doehmer J, Ward JM, Jefcoate CR, Gonzalez FJ. (1999) Cytochrome P450 CYP1B1 determines susceptibility to 7,12-dimethylbenz(a)anthracene-induced lymphomas. Pro Natl Acad Sciences USA 96:1977-1982.

Gammon MD, Sagiv SK, Eng SM, Shantakumar S, Gaudet MM, Teitelbaum SL, Britton JA, Terry MB, Wang LW, Wang Q, Stellman SD, Beyea J, Hatch M, Kabat GC, Wolff MS, Levin B, Neugut AI, Santella RM. (2004) Polycyclic aromatic hydrocarbon-DNA adducts and breast cancer: a pooled analysis. Arch Environ Health 59: 640-649.

Gammon MD, Santella RM, Neugut AI, Eng SM, Teitelbaum SL, Paykin A, Levin B,Terry MB, Young TL, Wang LW, Wang Q, Britton JA, Wolff MS, Stellman SD, Hatch M, Kabat GC, Senie R, Garbowski G, Maffeo C, Montalvan P, Berkowitz G, Kemeny M, Citron M, Schnabel F, Schuss A, Hajdu S, Vinceguerra V. (2002) Environmental toxins and breast cancer on Long Island. I. Polycyclic aromatic hydrocarbon DNA adducts. Cancer Epidemiol Biomarkers Prev 11: 677-85.

Gonzalez FJ, Gelboin HV. (1994) Role of human cytochromeP450 in the metabolic activation of chemical carcinogens and toxins. Drug Metab Rev 26: 165-183.

Goth-Goldstein R, Russell M, Singh R, Weyand EH. (2001) 7H-Benzo[c]fluorene:DNA adduct formation in MCF7 and HepG2 cells. The Toxicologogists 60:1817.

Goth-Goldstein R, Erdmann CA, Russell MR (2003) Cytochrome P4501B1 expression in 
normal breast tissue. Polycyclic Aromatic Compounds 23: 259- 275.

Hayes CL, Spink DC, Spink BC, Cao JQ, Walker NJ, Sutter TR. (1996) $17 \beta$-estrdiol hydroxylation catalyzed by human cytochrome P4501B1. Pro Nat Aca Sciences 93: 9776-9781.

Inoue, K, Asao, T., Shimada, T. (2000) Ethnic-related differences in the frequency distribution of genetic polymorphisms in the CYP1A1 and CYP1B1 genes in Japanese and Caucasian populations. Xenobiotica 30: 285-95.

Justenhoven C, Hamann U, Schubert F, Zapatka M, Pierl CB, Rabstein S, Selinski S, Mueller T, Ickstadt K, Gilbert M, Ko YD, Baisch C, Pesch B, Harth V, Bolt HM, Vollmert C, Illig T, Eils R, Dippon J, Brauch H. (2008) Breast cancer: a candidate gene approach across the estrogen metabolic pathway. Breast Cancer Res Treat 108:137149.

Kazerouni N, Sinha R, Hsu C-H, Greenberg A, Rothman N. (2001) Analysis of 200 food items for benzo[a]pyrene and estimation of its intake in an epidemiologic study. Food and Chem Toxicol 39: 423-436.

Lagueux J, Pereg D, Ayotte P, Dewailly E, Poirier GG. (1999) Cytochrome P450 CYP1A1 enzyme activity and DNA adducts in placenta of women environmentally exposed to organochlorines. Environ Res 80: 369-382.

LaKind JS, Wilkins AA, Bates MN. (2007) Human breast biomonitoring and environmental chemicals: use of breast tissues and fluids in breast cancer etiologic research. JESEE 17: 525-540.

Larsen MC, Angus WG, Brake PB, Eltom S, Sukow KA, Jefcoate CR. (1998) Characterization of CYP1B1 and CYP1A1 expression in human mammary epithelial cells: role of the aryl hydrocarbon receptor in polycyclic aromatic hydrocarbon metabolism. Cancer Res 58: 2366-2374.

Li D., Wang M., Ghingra K., Hittelman W.N. (1996) Aromatic DNA adducts in adjacent tissues of breast cancer patients: clues to breast cancer etiology. Cancer Res 56:287293.

Li D, Wang M, Firozi PF, Chang P, Zhang W, Baer-Dubowska W, Moorthy B, Vulimiri SV, Goth-Goldstein R, Weyand EH, DiGiovanni J. (2002) Characterization of a major aromatic DNA adduct detected in human breast tissues, Env Mol Mutagenesis 39:193200.

Madigan MP, Ziegler RG, Benichou J, Byrne C, Hoover R. (1996) Proportion of breast cancer cases in the United States explained by well-established risk factors J Natl Cancer Inst 87: 1681-1685.

Mammen, J.S., Pittman, G.S., Abou-Zahr, F., Bejjani, B. A., Bell, D. A., Strickland, P.T., Sutter, T. R. (2003) Single amino acid mutation, but not common polymorphisms, decrease the activity of CYP1B1 against (-) benzo[a]pyrene-7R-trans-7,8-dihydrodiol. Carcinogenesis 24: 1247-1255.

Nebert DW, Gonzales FJ. (1987). P450 genes: structure, evolution, and regulation. Ann Rev Biochem 56: 945-993. 
Paracchini V, Raimondi S, Gram IT, Kang D, Kocabas NA, Kristensen VN, Li D, Parl FF, Rylander-Rudqvist T, Soucek P, Zheng W, Wedren S, Taioli E. (2007) Meta- and pooled analyses of the cytochrome P-450 1B1 Val432Leu polymorphism and breast cancer: a HuGE-GSEC review. Am J Epidemiol 165: 115-125.

Safe SH. (1995) Modulation of gene expression and endocrine response pathways by 2.3.7.8-tetrachlorodibenzo-p-dioxin and related compounds. PharmacTher 67: 247-281.

Shantakumar S, Gammon MD, Eng SM, Sagiv SK, Gaudet MM, Teitelbaum SL, Britton JA, Terry MB, Paykin A, Young TL, Wang LW, Wang Q, Stellman SD, Beyea J, Hatch M, Camann D, Prokopczyk B, Kabat GC, Levin B, Neugut AI, Santella RM. (2005) Residential environmental exposures and other characteristics associated with detectable PAH-DNA adducts in peripheral mononuclear cells in a population-based sample of adult females. J Expo Anal Environ Epidemiol 15: 482-490.

Shimida T, Hayes C, Yamazaki H, Amin S, Hecht SS, Guengrich P, Sutter T. (1996) Activation of chemically diverse procarcinogens by human cytochrome P-450 1B1. Cancer Res 56: 2979-2984.

Sillanpää P, Heikinheimo L, Kataja V, Eskelinen M, Kosma VM, Uusitupa M, Vainio H, Metsola K, Hirvonen A. (2007) CYP1A1 and CYP1B1 genetic polymorphisms, smoking and breast cancer risk in a Finnish Caucasian population. Breast Cancer Res Treat 104: 287-297.

Steck SE, Gaudet MM, Eng SM, Britton JA, Teitelbaum SL, Neugut AI, Santella RM, Gammon MD. (2007) Cooked meat and risk of breast cancer-lifetime versus recent dietary intake. Epidemiology 18: 373-82.

Tsuchiya Y, Nakajima M, Takagi S, Taniya T, Yokoi T. (2006) MicroRNA regulates the expression of human cytochrome P450 1B1. Cancer Res 66:9090-9098.

Wen W, Ren Z, Shu XO, Cai Q, Ye C, Gao YT, Zheng W. Expression of cytochrome P450 $1 \mathrm{~B} 1$ and catechol-O-methyltransferase in breast tissue and their associations with breast cancer risk. Cancer Epidemiol Biomarkers Prev 16:917-20, 2007.

Weyand EH, Ma BL, Yarborough A, Frimpong B, Rozett K. (2000) Comparative analysis of chemical:DNA adduct formation in mouse lung following dermal application of coal tar shampoo and MGP tar. The Toxicologists 54:1260A.

Whitlock JP Jr. (1999) Induction of cytochrome P4501A1. Ann Rev Pharmacol Toxicol 39: 103-25.

Widschwendter M, Siegmund KD, Müller HM, Fiegl H, Marth C, Müller-Holzner E, Jones PA, Laird PW. (2004) Association of breast cancer DNA methylation profiles with hormone receptor status and response to tamoxifen. Cancer Res 64:3807-13.

Wiencke JK, Thurston SW, Kelsey KT, Varkonyi A, Wain JC, Mark EJ, Christiani DC. (1999) Early age at smoking initiation and tobacco carcinogen DNA damage in the lung. J Natl Cancer Inst. 91:614-619.

Zhu BT, Conney AH. (1998) Functional role of estrogen metabolism in target cells: review and perspectives. Carcinogenesis. 19:1-27. 


\section{Appendix}

We had originally planned to evaluate CYP1B1 expression levels relative to the $\beta$-actin housekeeping gene. Because the specimens collected in this study are a complex mixture of varying cell types, they differ in epithelial cell content. We had planned to correct for epithelial cell content by determining 18-keratin expression which is a specific marker of epithelial cells. We compared 18-keratin and CYP1B1 expression in fractions of a breast tissue specimen prepared according to Stampfer (1985) by stepwise filtration through filters with decreasing pore size from 150 to $51 \mu$. The tissue retained by the $150 \mu$ filter contains fairly pure epithelial cells. Calibrator-normalized RT-PCR was performed with the LightCycler instrument. The specificity of each product was checked by melting curve analysis. The expression level in the sample was corrected by the total amount of RNA added to the reaction and then normalized to our calibrator sample isolated from the HMEC184 cell line.

When measuring CYP1B1 expression relative to keratin or actin in different breast tissue fractions we found that CYP1B1 expression levels are incorrectly represented. (Table 1). We concluded that neither house-keeping gene is an appropriate choice for the breast tissue specimens used in this study and decided to quantitate the absolute amount of CYP1B1 transcript found in each specimen.

Table A1: Comparison of CYP1B1, keratin-18 and $\beta$-actin expression levels in different fractions of a single breast tissue specimen determined by Calibrator-normalized RT-PCR.

\begin{tabular}{|l|l|l|l|l|l|}
\hline $\begin{array}{l}\text { Filter size } \\
\text { (micron) }\end{array}$ & CYP1B1 & keratin-18 & $\boldsymbol{\beta}$-actin & $\begin{array}{l}\text { CYP1B1/ } \\
\text { keratin }\end{array}$ & $\begin{array}{r}\text { CYP1B1/ } \\
\boldsymbol{\beta} \text {-actin }\end{array}$ \\
\hline 150 & 0.21 & 0.37 & 0.35 & 0.56 & 0.61 \\
\hline 95 & 0.15 & 0.06 & 0.10 & 2.70 & 1.50 \\
\hline 50 & 0.21 & 0.08 & 0.21 & 2.81 & 1.01 \\
\hline filtrate & 0.09 & 0.04 & 0.07 & 2.05 & 1.36 \\
\hline
\end{tabular}

We developed a Quantitative RT-PCR assay for CYP1B1 using the LightCycler. We synthesized an RNA quantitation standard for the CYP1B1 gene. Each run of the LightCycler included a dilution series of this standard. The standard and the CYP1B1 gene transcript were reverse transcribed and amplified together at equal efficiencies to control for each step of the assay. The CYP1B1 expression level in an unknown sample was determined by extrapolating from a curve produced from the dilution series of the quantitation standard (Figure 1).

The RNA quantitation standard was produced by cloning the CYP1B1 PCR fragment into a plasmid carried by an e.coli cell line. The plasmid was produced in large quantities by growing the E. coli. cells. The plasmid carrying the CYP1B1 gene fragment was isolated and purified. The RNA quantitation standard was produced by in vitro transcription of the linearized plasmid. The amount of the CYP1B1 RNA quantitation standard was accurately determined by a fluorescent assay. 
Two possible sources of variation in the quantitative PCR assay were characterized:

(1) reproducibility of the QS dilution series and (2) variability in the RNA isolation. When analyzing a dilution series of the QS at five different concentration levels (from 10,000 fg to $1 \mathrm{fg}$ ), each in triplicate the variance was less than $1 \%$ at each concentration level (see Fig.1). To measure the variability in the isolation procedure, the RNA from one specimen was isolated in triplicate and then analyzed by the RT-PCR assay for CYP1B1. The variance in transcript level was $6.6 \%$. The average transcript level was 9.93 fg per $500 \mathrm{ng}$ total RNA $(\mathrm{SD}=0.66)$.

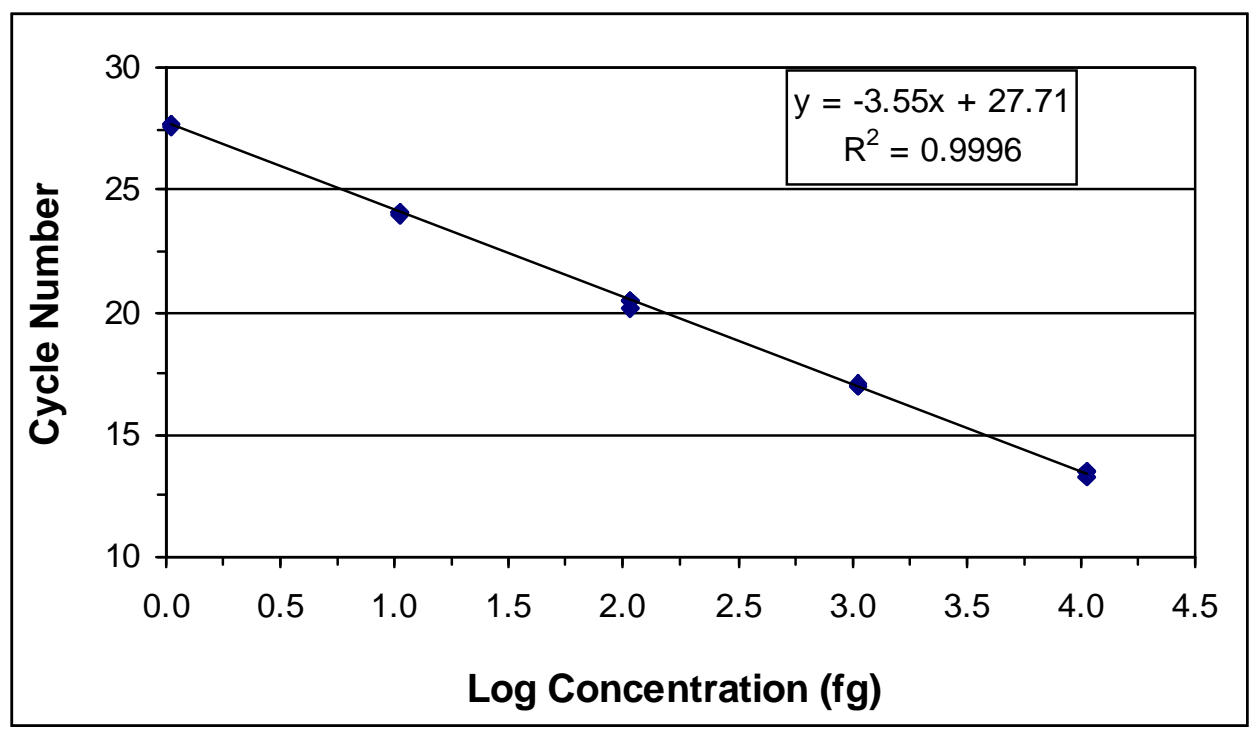

Figure A1. Standard curve of CYP1B1 RNA Quantitation Standard measured on the LightCycler.

To measure the variability in the isolation procedure, the RNA from one specimen (\#128) was isolated in triplicate and then analyzed by the RT-PCR assay for CYP1B1. The average transcript level was $9.93 \mathrm{fg}$ per $500 \mathrm{ng}$ total RNA $(\mathrm{SD}=0.66)$. The variance is 6.6 $\%$; however, an initial measurement of the CYP1B1 transcript levels made from RNA isolated from specimen \#128 six months earlier resulted in a higher level, 39.50 fg per 500 ng total RNA. This suggests that storage time of the specimen is critical and that RNA should be isolated as soon as possible.

RNALater turned out to be very effective in preserving the RNA in the specimens, so that even specimens from the first shipment, which arrived at room temperature, provided RNA and the quantitation of CYP1B1 transcript was comparable to repeat measurements with additional tissue sent in the second shipment. 
Table A2. Results from CYP1B1 gene transcript measurement of specimen \#128 with RNA isolation in triplicate. Transcript levels are expressed as fg/500ng total RNA used in the reverse transcription.

\begin{tabular}{|c|c|}
\hline Specimen ID & CYP1B1 (fg/500ng RNA) \\
\hline $128-1$ & 9.34 \\
\hline $128-2$ & 10.64 \\
\hline $128-3$ & 9.81 \\
\hline
\end{tabular}

